\title{
The Effect of Conflict Resolution Training on the Conflict Resolution Skills of Nursing Students
}

\author{
Çatışma Çözümü Eğitiminin Hemşirelik Öğrencilerinin Çatışma Çözüm Becerisine Etkisi
}

\author{
Özlem ŞAHİN ALTUN, Mine EKİNCI
}

\section{SUMMARY}

Objectives: The aim of this study is to determine the effect of conflict resolution training, on the nursing student's conflict resolution skills. Pre-test and post-test control group research was conducted as a semiexperimental model.

Methods: At the and the sample group of the study comprised of 105 students: $n=62$ for experimental group with a low score mean (110 and below) and $n=43$ for control group with the same total score. Conflict Resolution Training was given to the experimental group between October, 4, 2010 and December, 17, 2010. Posttests (an student description form and the conflict resolution scale) were conducted on December, 24, 2010, a week after training ended. No intervention was conducted on the control group, and posttests (an student description form and the conflict resolution scale) were conducted on December, 23, 2010.

Results: According to the pretest score means of experimental and control group students obtained from the conflict resolution scale, there was no statistically significant difference between the overall total score and the sub-scales ( $p>0.05$ ). According to the posttest score means of experimental and control group students obtained from the conflict resolution scale, there was no statistically significant difference between the total score of "resting skills" and "anger management" subscale ( $p>0.05)$; however, there was a statistically significant difference between the overall score mean, and the score means of the other subscales $(p<0.05)$. The overall score mean of conflict resolution scale for students in the experimental group before conflict resolution training was $85.03 \pm 10.57$, while after conflict resolution training this average increased to $101.48 \pm 14.24$. There was a statistically significant difference between the pretest score mean and posttest score mean for students in the experimental group ( $p<0.05)$.

Conclusion: Study result, concluded that conflict resolution training, increased conflict resolution skills of nursing students that participated in the training program.

Keywords: Conflict; conflict resolution; nursing student.

\section{ÖZET}

Amaç: Araştırma hemşirelik öğrencilerine verilen çatışma çözümü eğitiminin; çatışma çözüm becerisine etkisinin belirlenmesi amacıyla yapıldı. Araştırma ön test ve son test kontrol gruplu yarı deneysel olarak yürütüldü.

Gereç ve Yöntem: Araştırmanın örneklemini 62 deney, 43 kontrol olmak üzere 105 öğrenci oluşturdu. Deney grubuna 04 Ekim-17 Aralık 2010 tarihleri arasında Çatışma Çözüm Eğitimi verildi. Eğitimden bir hafta sonra 24 Aralık 2010 tarihinde son-testler (öğrenci tanıtım formu ve çatışma çözme ölçeği) uygulandı. Kontrol grubuna ise herhangi bir girişim uygulanmadan 23 Aralık 2010 tarihinde son-testler (öğrenci tanıtım formu ve çatışma çözme ölçeği) uygulandı.

Bulgular: Deney ve kontrol grubundaki öğrencilerin çatışma çözme ölçeğine göre ön test puan ortalamaları karşılaştırıldığında, ölçek toplam puan ortalaması ve alt boyutlar arasında istatistiksel olarak önemli fark olmadığı belirlendi ( $p>0.05)$. Deney ve kontrol grubundaki öğrencilerin çatışma çözme ölçeğine göre son test puan ortalamaları karşılaştırıldığında, ölçeğin alt boyutlarından dinleme becerileri ve öfke kontrolü becerisi puan ortalamalarında istatistiksel olarak önemli fark olmadığı ( $p>0.05$ ), ölçeğin diğer alt boyutlarında ve ölçek toplam puan ortalamaları arasında istatistiksel olarak önemli fark olduğu saptandı $(p<0.05)$. Deney grubundaki öğrencilerin çatışma çözüm eğitimi öncesi çatışma çözme ölçeği toplam puan ortalaması $85.03 \pm 10.57$, çatışma çözüm eğitimi sonrası ise toplam puan ortalaması 101.48 \pm 14.24 olarak belirlendi. Deney grubunun ön test-son test toplam puan ortalamaları arasındaki fark istatistiksel olarak önemli bulundu $(p<0.05)$.

Sonuç: Araştırma sonucunda, çatışma çözümü eğitim programına katılan hemşirelik öğrencilerinin çatışma çözüm becerilerinde artış olduğu bulundu.

Anahtar sözcükler: Çatı̧ma; çatışma çözümü; hemșirelik öğrencisi.

\section{Introduction}

The conflict may be defined as a person or group's having the difficulty to make a choice and the deterioration in the

Ataturk University, Faculty of Health Science, Erzurum

Correspondence (illetişim): Dr. Özlem ŞAHIN ALTUN.

e-mail (e-posta): oz_sahin@mynet.com

Psikiyatri Hemşireliği Dergisi 2015;6(3):105-113

Journal of Psychiatric Nursing 2015;6(3):105-113

Doi: 10.5505/phd.2015.63856

Submitted (Geliş tarihi): 14.07.2014 Accepted (Kabul tarihi): 07.10.2015 decision-making mechanisms as a result of this difficulty. Interpersonal conflict, on the other hand, is a condition of disagreement experienced between two or more individuals. ${ }^{[1]}$

The communication is a psychosocial process based on the relationship of two individuals. ${ }^{[2]}$ As days pass, people face a more complex and intense pattern of interpersonal relationships. This situation causes the deterioration in interpersonal relationships, interpersonal conflicts, alienation from people, and feeling loneliness. ${ }^{[3]}$

Interpersonal conflicts are regarded as the source of improvement and creativity despite being considered as a negati- 
ve situation required to be avoided at first sight. The conflict, from this point of view, takes place in the roots of social/personal change and development and takes part in appearing a positive change as a natural consequence of interactions and the choices made in these interactions. This approach, which have significant importance especially in terms of their solutions, assesses conflicts as a situation that is the beginning of change and development and required to be taken normally instead of a problem which needs to be avoided. ${ }^{[4,5]}$

This conflict perception brings along many positive results by contributing to improve interpersonal relations, appear creativities, arise new thoughts and ideas, improve good decision-making and mutual understanding, increase job performance, and make individuals more positive and constructive. ${ }^{[4,5]}$

Nursing is a profession with a scientific basis. Therefore, nurses with bachelor's degree are expected to have the skills of doing the planning, developing a investigative point of view, having self-expression, conducting the training, communicating effectively and resolving conflicts as well as being qualified with adequate knowledge regarding their profession. ${ }^{[6,7]}$

Nursing education plays a major role in development of behaviours of effective communication and conflict resolution. School is an environment where interpersonal relations are intensively experienced. Students are constantly in communication both with one another, and their teachers and the medical team in their practice areas. Having a continuous communication occasionally brings along conflicts. This is because each person has their own way of thinking, values, and beliefs. In other words, each person analyses incidents from a different perspective, makes different interpretations, and gives different reactions; which occasionally causes conflicts and clashes in daily life. ${ }^{[1]}$

Constructive resolution of conflicts in schools and hospitals improves teamwork; reduces burnout of team members, and therefore increases more job satisfaction. It encourages students to have the creative thinking; it increases the research tendency; solution is sought for problems that have remained unsolved; each person expresses their own opinion and increases the motivation; individuals examine their knowledge and capacities; and positive results are obtained; and it enables patients to receive better care. ${ }^{[8-11]}$

Results of conflicts which are resolved destructively or are not resolved result in deterioration of business relations, and emergence of physical and mental disorders based on stress accumulation. Individuals who consistently avoid conflicts feel weak, their self-confidence decrease and this situation also adversely affects patients to have a good care. ${ }^{[8,12-15]} \mathrm{In}$ this context, conflict leads to dynamism in its environment and becomes an integral part of development when appropriate approaches are used. The biggest factor in resolving the problem in conflict is the attitude and skill of the person managing the conflict. ${ }^{[16]}$

It is stated that the inadequate importance given to improving the skills of nurses in resolving conflicts during their school years is effective on the fact that they frequently experience conflict processes in their business lives. ${ }^{[17,18]}$

Once individuals encounter any conflict, they generally react by using verbal or physical violence, trying to ignore it, acting timidly or accusing themselves. However; none of these solutions is effective on resolving such conflict; and unresolved conflicts generally cause emotional offenses, dissolution of friendships, anger, and frustration. ${ }^{[9]}$

Individuals who resolve conflicts are those with empathic skills who respect and listen to others; try to understand the needs of the individual with whom they are in conflict with while they have their own needs; are social, outgoing, and in possession of the power to control their anger. ${ }^{[19]}$

Majority of conflicts can be prevented with an effective conflict resolution training. Problems appearing to be simple can be resolved before they become more serious through timely intervention.

In literature, there has been no study conducted on the conflict resolution education for students of nursing. However, there have been many descriptive studies conducted in different fields by using various conflict scales. . $^{[3,10,16,17,20-29]}$ Researches done by giving the conflict resolution education on the other hand have been carried out in different groups towards nurses, university students and primary school students. Results of these researches concluded that the conflict resolution education program is effective in increasing the conflict resolution skill levels. ${ }^{[10,26,27,30-33]}$

\section{Purpose of the Study}

The purpose of the study is to determine the effect of conflict resolution education on the conflict resolution skill of the nursing students.

\section{Hypothesis of the Study}

H1: Conflict resolution education increases the conflict resolution skill scores of the nursing students.

\section{Methods}

\section{Type of the Study}

The study was designed as quasi-experimental model with pretest and posttest control group.

\section{Place and Date of the Study}

The data of the study were collected in Ataturk University, Faculty of Health Sciences and Erzincan University, 
School of Health Sciences between 29 September 2010 and 24 December 2010.

\section{Population and Sample Group of the Study}

The population of the study was consisted of seniors (174 students) of Ataturk University, Faculty of Health Sciences, Nursing Department and the seniors (49 students) of Erzincan University, School of Health Sciences, Nursing Department. Student Description Form and Conflict Resolution Scale were performed to the seniors of Ataturk University, Faculty of Health Sciences, Nursing Department and the seniors of Erzincan University, School of Health Sciences, Nursing Department. 62 students wishing to participate in the study among 75 seniors having lower grade point average (110 points and less) attending at Ataturk University, Faculty of Health Sciences, Nursing Department constituted the experimental group and 43 students having grade point average (110 points and less) among 49 seniors attending at Erzincan University, Health High School, Nursing Department constituted the control group.

The reason behind why the students in the experimental group and control group were taken from different schools is to prevent them from interacting. For this reason, $105 \mathrm{stu}-$ dents (62 for the experiment group, and 43 for the control group) constituted the sample group of the study.

\section{Data Collection Tools}

Description form, which specifies the socio-demographic characteristics of students, and Conflict Resolution Scale were used to collect the data.

\section{Student Description Form}

A student description form prepared by researchers in line with the literature in order to specify descriptive characteristics of students, and involving 7 questions, was used. ${ }^{[20-25]}$

\section{Conflict Resolution Scale}

Conflict Resolution Scale (CRS) was developed by Akbalık in 2001 in order to determine the conflict resolution skills of university students and assess conflict resolution education and peer mediation programs; she conducted its validity-reliability studies, as well. It is a 4-point Likert-type scale including 55 items (scored as 1,2,3, and 4). The scale is divided into 5 sub-scales. ${ }^{[19]}$ The Cronbach-Alpha reliability coefficient of this scale is 0.91 . The Cronbach-Alpha reliability coefficient of the scale in this study is 0.81 .

\section{Sub-Scales}

1. Skill of students to understand the person in conflict with them: This subscale covers the items $20,22,35,36,37,44,45$, $46,47,48,50,54$, and 55 . The lowest and the highest scores to be obtained from this subscale are 13 and 52 .

2. Listening skills: This subscale covers the items 3, 6, 7, 8,
$11,12,13,15,16,23,30,41,42$, and 43 . The lowest and the highest scores to be obtained from this subscale are 14 and 56.

3. Skill to focus on needs of both parties: This subscale involves the items $9,27,33,38,39,40,49,51,52$, and 53 . The lowest and the highest scores to be obtained from this subscale are 10 and 40 .

4. Social adaptation skill: This subscale includes the items 2, 4, 10, 14, 17, 18, 21, 26, 28, 29, 31, and 32. Minimum and maximum scores of this subscale are 12 and 48 .

5. Anger management skill: This subscale covers the items $1,5,19,24,25$, and 34 . The lowest and the highest scores to be obtained from this subscale are 6 and 24 .

The lowest score of the scale is 55 and the highest score is $220 .{ }^{[27]}$ Upon examination of means of the scale, the most used/less used conflict resolution method in case of conflict is determined. When total score of conflict resolution skill is $55-110,110.01-165$ and $165.01-220$, it is considered to be at low level, moderate level and high level, respectively. ${ }^{[34]}$

\section{Data Collection}

Pretests (student description form and conflict resolution scale) were performed to the experimental group. Students were asked to write a nickname on pretest data forms. 75 students obtaining a score lower than 110 from the Conflict Resolution Scale according to pretest results were invited to the study by declaring their nicknames. 75 students accepting to participate in the study were informed about the Conflict Resolution Education and then 62 students accepting to participate in the education received the Conflict Resolution Education between 04 October 2010 and 17 December 2010. Posttests (student description form and conflict resolution scale) were performed on 24 December 2010, one week after the education.

Pretests (student description form and conflict resolution scale) were executed to the control group. 43 students obtaining a score lower than 110 from the Conflict Resolution Scale according to pretest results were invited to the study by declaring their nicknames. 43 students accepting to participate in the study were included into the control group. Posttests (student description form and conflict resolution scale) were performed to the control group on 23 December 2010.

\section{Intervention}

The researcher applying the Conflict Resolution Education participated in the education seminar titled "Conflict Management" arranged by Ege University, Coordinatorship of My University Program on 15.01.2004 and received a certificate. The 10-session Conflict Resolution Education was given by the researcher to the 62 students accepting to participate in the Conflict Resolution Education between 04 Oc- 
tober 2010 and 17 December 2010. The sessions were given in the seminar hall of the Faculty of Health Sciences. Each session lasted one hour. The education was performed in two groups of 31 people. Teaching techniques of theoretical information, group discussion, brain storming, role-play, case study, and home works were used (in the study) each week. The posttests (student description form and conflict resolution scale) were performed to 62 students participating in the Conflict Resolution Education program on 24 December 2010, one week after the education.

\section{Content of the Conflict Resolution Training Programme}

$1^{\text {st }}$ Session: pre-tests were applied by making pre-interviews (student introduction form and conflict resolution scale).

$2^{\text {nd }}$ Session: Forming the group; having knowledge about conflicts and nature of conflicts

1. Meeting with students,

2. Determination of individual goal

3. Determination of rules to be followed within the group

4. Having knowledge about the purpose and the content of the conflict resolution programme

5. Having knowledge about the conflict concept; nature of conflict, and the fact that conflict is a natural part of life

$3^{r d}$ session: Ensuring trust environment, understanding the causes of conflict, and reactions given to the conflict

1. Ensuring trust environment

2. Learning about the causes of conflicts

3. Learning about the reactions given to conflicts

$4^{\text {th }}$ Session: Developing the skill to listen effectively; speak constructively; listen to understand feelings and distinguish incidents with emotions,

1. Gaining the skills of effective listening and constructive speech

2. Gaining the skill of listening to understand feelings

3. Gaining the skill to distinguish feelings and incidents

$5^{\text {th }}$ Session: Understanding the difference between the "you language" and "I language" and bringing the skill to use "I language"

1. Making them understand the difference "You language" and "I Language"

$6^{\text {th }}$ Session: Developing the skill to cope with the anger

1. Knowing the effect of anger on communication

2. Being able to realize the reaction they give when they get angry $7^{\text {th }}$ Session: Being able to understand how their impulsive, passive or aggressive behaviour characteristics may affect the result of the conflict

1. Knowing the properties of impulsive, passive, or aggressive behaviours

2. Comprehending the relationship between behaviour types and conflict resolution methods

$8^{t h}$ Session: Developing the skill of empathic thinking and analysing the situation from the perspective of the other

1. Gaining empathic understanding

2. Comprehending the importance of empathy in interpersonal communication

3. Gaining the skill to analyse the situation from the perspective of the other

$9^{\text {th }}$ Session: Comprehending the conflict resolution methods; through which methods such conflicts can be solved and how each of these methods can affect the result of the conflict

1. Comprehending the results of the reactions given to conflicts

2. Comprehending the conflict resolution methods

3. Comprehending how each of the conflict resolution methods can affect the result of the conflict

$10^{\text {th }}$ Session: Gaining the skill to use the first four steps of conflict resolution

1. Gaining the skill to create a positive and effective environment

- Gaining the skill to ensure personal preparation

- Gaining the skill to make proper timing

- Gaining the skill to determine proper place

- Gaining the skill to start the speech with a suitable opening sentence

2. Gaining the skill to clarify perceptions

3. Gaining the skill to focus on personal and shared needs

4. Gaining the skill to share positive energy

$11^{\text {th }}$ Session: Gaining the skill to use the last four steps of the conflict resolution process

1. Gaining the skill to focus on future at first and then try to understand what occurred in the past

2. Gaining the skill to develop options

3. Gaining the skill to determine the options that are applicable

4. Gaining the skill to make fair agreements that can sa- 
tisfy both parties

5. General Review of the Conflict Resolution Training Programme

$12^{\text {th }}$ Session: Post-tests (student introductory form and conflict resolution scale) were applied.

\section{Analysis of Data}

Data were assessed on the computer by using the software program SPSS Windows 17.0 (Statistical Package For Social Science). Percentage, chi-square test, Mann-Whitney $\mathrm{U}$, Kruskal Wallis, mean, standard deviation, and t test were used to conduct the statistical analysis of data.

\section{Ethical Principles of the Study}

Written permission of the institutions in which the study would be conducted was taken before commencing the research. The utilization permit for the measurement instrument to be used in the study was taken in written. Moreover, the thesis proposal was submitted to Ethics Committee of Ataturk University, Institute of Health Sciences and its approval was taken. Students were informed about the purpose of the study and their oral consents were taken. By this way, the "informed consent principle" was executed as the ethical principle. "Autonomy" principle was taken into consideration by stating that the students would be free to withdraw from the study at any time and the "Privacy and Privacy Protection" principle was considered by indicating that personal information is preserved after being shared with the researcher. "De-identification and Security" principle was complied by declaring that the obtained information and the identity of the respondent would be kept confidential. ${ }^{[34,35]}$ The students in the control group were said to be able to receive the education given to the students in the experimental group when desired.

\section{Results}

Table 1 illustrates the distribution of descriptive characteristics of the students included in the scope of study. Examining the distribution of the groups in terms of age, it is determined that $80.6 \%$ of the students in the experimental group are $21-23$ years old and $81.4 \%$ of the students in the control group are 21-23 years old; the difference between the

Table 1. Comparison of descriptive characteristics of experimental and control groups

\begin{tabular}{|c|c|c|c|c|c|c|c|}
\hline \multirow[t]{2}{*}{ Socio-demographic characteristics } & \multicolumn{2}{|c|}{$\begin{array}{c}\text { Exp. group } \\
(n=62)\end{array}$} & \multicolumn{2}{|c|}{$\begin{array}{c}\text { Control group } \\
(n=43)\end{array}$} & \multicolumn{2}{|c|}{$\begin{array}{c}\text { Total } \\
(n=105)\end{array}$} & \multirow[t]{2}{*}{$\begin{array}{c}\text { Significance } \\
\text { level }\end{array}$} \\
\hline & $\mathrm{n}$ & $\%$ & $\mathrm{n}$ & $\%$ & $\mathrm{n}$ & $\%$ & \\
\hline \multicolumn{8}{|l|}{ Age } \\
\hline $18-20$ & 6 & 9.7 & 5 & 11.6 & 11 & 10.5 & $X^{2}=0.310$ \\
\hline $21-23$ & 50 & 80.6 & 35 & 81.4 & 85 & 81.0 & $S D=2$ \\
\hline 24 years and older & 6 & 9.7 & 3 & 7.0 & 9 & 8.5 & $p>0.05$ \\
\hline \multicolumn{8}{|l|}{ Gender } \\
\hline Female & 51 & 82.3 & 33 & 76.7 & 84 & 80.0 & $X^{2}=0.482$ \\
\hline Male & 11 & 17.7 & 10 & 23.3 & 21 & 20.0 & $\begin{array}{c}S D=1 \\
p>0.05\end{array}$ \\
\hline \multicolumn{8}{|l|}{ The place of longest residence } \\
\hline City & 34 & 54.8 & 24 & 55.8 & 58 & 55.2 & $X^{2}=1.194$ \\
\hline Town & 23 & 37.1 & 13 & 30.2 & 36 & 34.3 & $S D=2$ \\
\hline Village & 5 & 8.1 & 6 & 14.0 & 11 & 10.5 & $p>0.05$ \\
\hline \multicolumn{8}{|l|}{ Family type } \\
\hline Nuclear family & 51 & 82.3 & 34 & 79.1 & 85 & 81.0 & $X^{2}=0.167$ \\
\hline Extended family & 11 & 17.7 & 9 & 20.9 & 20 & 19.0 & $\begin{array}{c}S D=1 \\
p>0.05\end{array}$ \\
\hline \multicolumn{8}{|l|}{ Mother's education } \\
\hline Illiterate & 9 & 14.5 & 8 & 18.6 & 17 & 16.2 & $X^{2}=3.150$ \\
\hline Literate & 6 & 9.7 & 5 & 11.6 & 11 & 10.5 & $S D=4$ \\
\hline Primary school & 32 & 51.6 & 24 & 55.8 & 56 & 53.3 & $p>0.05$ \\
\hline Secondary school & 7 & 11.3 & 1 & 2.3 & 8 & 7.6 & \\
\hline High school & 8 & 12.9 & 5 & 11.6 & 13 & 12.4 & \\
\hline \multicolumn{8}{|l|}{ Father's education } \\
\hline Literate & 3 & 4.9 & 5 & 11.6 & 8 & 7.6 & $X^{2}=3.115$ \\
\hline Primary school & 27 & 43.5 & 17 & 39.5 & 44 & 41.9 & $\mathrm{SD}=4$ \\
\hline Secondary school & 11 & 17.7 & 6 & 14 & 17 & 16.2 & $p>0.05$ \\
\hline High school & 15 & 24.2 & 8 & 18.6 & 23 & 21.9 & \\
\hline College & 6 & 9.7 & 7 & 16.3 & 13 & 12.4 & \\
\hline \multicolumn{8}{|l|}{ Family's attitude } \\
\hline Authoritative/over-controlling & 5 & 8.1 & 10 & 23.3 & 15 & 14.3 & $X^{2}=4.785$ \\
\hline Democratic and supportive & 57 & 91.9 & 33 & 76.7 & 90 & 85.7 & $\begin{array}{c}S D=1 \\
p>0.05\end{array}$ \\
\hline
\end{tabular}


groups in terms of age is statistically insignificant ( $p>0.05)$.

Examining the distribution of the groups in terms of gender, it is determined that $82.3 \%$ of the students in the experimental group and $76.7 \%$ of the students in the control group are female; the difference between the groups in terms of gender is statistically insignificant ( $p>0.05)$.

Examining the distribution of the groups in terms of family type, it is found out that $82.3 \%$ of the students in the experimental group and $79.1 \%$ of those in the control group live in nuclear family; the difference between the groups in terms of family type is statistically insignificant ( $p>0.05)$.

When the distribution of the groups in terms of family's attitude is analyzed, it is detected that $8.1 \%$ of the students in the experimental group have an authoritative/over-controlling family, and $91.9 \%$ have a democratic and supportive family while $23.3 \%$ of the students in the control group have an authoritative/over-controlling family, and $76.7 \%$ have a democratic and supportive family; the difference between the groups in terms of family's attitude is statistically insignificant $(\mathrm{p}>0.05)$.

Table 2 illustrates the comparison of CRS pretest mean scores of students in the experimental and control groups. The scores obtained by students in the experimental group from subscales of the scale are as follows: $21.17 \pm 4.32$ for skill of students to understand the person in conflict with them, $21.19 \pm 3.46$ for listening skills, $14.91 \pm 3.03$ for skill to focus on needs of both parties, $18.29 \pm 3.49$ for social adaptation skill, and $9.45 \pm 2.59$ for anger management skill; the scores obtained by those in the control group from said subscales are as follows: $22.60 \pm 4.82$ for skill of students to understand the person in conflict with them, $22.72 \pm 3.45$ for listening skills, $15.60 \pm 3.18$ for skill to focus on needs of both parties,
$18.81 \pm 2.80$ for social adaptation skill, and $9.55 \pm 2.42$ for anger management skill. The difference between experimental group and control group in terms of mean scores of subscales of the scale in the pretest is statistically insignificant $(p>0.05)$.

Table 2 presents the comparison of CRS posttest mean scores of students in the experimental and control groups. The scores obtained by students in the experimental group from subscales of the scale are as follows: $25.66 \pm 5.25$ for skill of students to understand the person in conflict with them, $23.88 \pm 4.25$ for listening skills, $19.95 \pm 5.72$ for skill to focus on needs of both parties, $21.11 \pm 3.83$ for social adaptation skill, and $10.87 \pm 2.40$ for anger management skill; on the other hand, the scores obtained by those in the control group from said subscales are as follows: $21.86 \pm 4.65$ for skill of students to understand the person in conflict with them, $23.13 \pm 4.45$ for listening skills, $16.81 \pm 3.50$ for skill to focus on needs of both parties, $19.44 \pm 3.69$ for social adaptation skill, and $10.06 \pm 2.49$ for anger management skill. While the difference between experimental and control groups in terms of mean scores of the subscales "listening skills" and "anger management skill" in the posttest is statistically insignificant ( $p>0.05)$, the difference between the groups in terms of total mean score and mean scores of the subscales "skill of students to understand the person in conflict with them", " skill to focus on needs of both parties ", and "social adaptation skill" in the posttest is statistically significant $(p<0.05)$.

Table 3 illustrates the comparison of CRS pretest-posttest mean scores of students in the experimental group. The scores obtained by them from subscales of the scale in the pretest are $21.17 \pm 4.32$ for skill of students to understand the person in conflict with them, $21.19 \pm 3.46$ for listening skills, $14.91 \pm 3.03$ for skill to focus on needs of both parties, $18.29 \pm 3.49$ for social adaptation skill, and $9.45 \pm 2.59$ for

Table 2. Comparison of CRS pretest-posttest mean scores of students in the experimental and control groups

\begin{tabular}{|c|c|c|c|c|c|c|}
\hline & \multicolumn{6}{|c|}{ SUB-SCALES } \\
\hline & $\begin{array}{l}\text { Skill of students } \\
\text { to understand } \\
\text { the person in } \\
\text { conflict with } \\
\text { them }\end{array}$ & Listening skills & $\begin{array}{l}\text { Skill to focus on } \\
\text { needs of both } \\
\text { parties }\end{array}$ & $\begin{array}{c}\text { Social } \\
\text { adaptation } \\
\text { skill }\end{array}$ & $\begin{array}{c}\text { Anger } \\
\text { management } \\
\text { skill }\end{array}$ & Total score \\
\hline & Mean \pm SD & Mean \pm SD & Mean \pm SD & Mean \pm SD & Mean $\pm S D$ & Mean \pm SD \\
\hline \multicolumn{7}{|l|}{ Pretest } \\
\hline Exp. & $21.17 \pm 4.32$ & $21.19 \pm 3.46$ & $14.91 \pm 3.03$ & $18.29 \pm 3.49$ & $9.45 \pm 2.59$ & $85.03 \pm 10.57$ \\
\hline Control & $22.60 \pm 4.82$ & $22.72 \pm 3.45$ & $15.60 \pm 3.18$ & $18.81 \pm 2.80$ & $9.55 \pm 2.42$ & $89.30 \pm 9.50$ \\
\hline Test and & $t=1.587$ & $\mathrm{t}=2.223$ & $t=1.116$ & $t=.817$ & $\mathrm{t}=.212$ & $\mathrm{t}=2.120$ \\
\hline$p$ value & $p=0.116$ & $p=.861$ & $p=.267$ & $p=.416$ & $\mathrm{p}=.832$ & $p=.054$ \\
\hline \multicolumn{7}{|l|}{ Posttest } \\
\hline Exp. & $25.66 \pm 5.25$ & $23.88 \pm 4.25$ & $19.95 \pm 5.72$ & $21.11 \pm 3.83$ & $10.87 \pm 2.40$ & $101.48 \pm 14.24$ \\
\hline Control & $21.86 \pm 4.65$ & $23.13 \pm 4.45$ & $16.81 \pm 3.50$ & $19.44 \pm 3.69$ & $10.06 \pm 2.49$ & $91.32 \pm 11.79$ \\
\hline Test and & $t=3.817$ & $t=.868$ & $t=3.202$ & $t=2.230$ & $t=1.654$ & $\mathrm{t}=3.848$ \\
\hline $\mathrm{p}$ value & $p=0.000$ & $\mathrm{p}=.387$ & $p=.002$ & $p=.028$ & $p=.101$ & $p=.000$ \\
\hline
\end{tabular}


Table 3. Comparison of CRS pretest-posttest mean scores of experimental and control groups

\begin{tabular}{|c|c|c|c|c|c|c|}
\hline & \multicolumn{6}{|c|}{ SUB-SCALES } \\
\hline & $\begin{array}{l}\text { Skill of students } \\
\text { to understand } \\
\text { the person in } \\
\text { conflict with } \\
\text { them }\end{array}$ & Listening skills & $\begin{array}{l}\text { Skill to focus on } \\
\text { needs of both } \\
\text { parties }\end{array}$ & $\begin{array}{l}\text { Social } \\
\text { adaptation } \\
\text { skill }\end{array}$ & $\begin{array}{c}\text { Anger } \\
\text { management } \\
\text { skill }\end{array}$ & Total score \\
\hline & Mean \pm SD & Mean \pm SD & Mean \pm SD & Mean \pm SD & Mean \pm SD & Mean \pm SD \\
\hline \multicolumn{7}{|l|}{ EXP. } \\
\hline Pretest & $21.17 \pm 4.32$ & $21.19 \pm 3.46$ & $14.91 \pm 3.03$ & $18.29 \pm 3.49$ & $9.45 \pm 2.59$ & $85.03 \pm 10.57$ \\
\hline Posttest & $25.66 \pm 5.25$ & $23.88 \pm 4.25$ & $19.95 \pm 5.72$ & $21.11 \pm 3.83$ & $10.87 \pm 2.40$ & $101.48 \pm 14.24$ \\
\hline Test and & $t=5.658$ & $t=3.819$ & $t=6.368$ & $\mathrm{t}=4.986$ & $t=3.554$ & $t=8.118$ \\
\hline $\mathrm{p}$ value & $p=0.000$ & $p=.000$ & $p=.000$ & $p=.000$ & $p=.001$ & $p=.000$ \\
\hline \multicolumn{7}{|l|}{ CONTROL } \\
\hline Pretest & $22.60 \pm 4.82$ & $22.72 \pm 3.45$ & $15.60 \pm 3.18$ & $18.81 \pm 2.80$ & $9.55 \pm 2.42$ & $89.30 \pm 9.50$ \\
\hline Posttest & $21.86 \pm 4.65$ & $23.13 \pm 4.45$ & $16.81 \pm 3.50$ & $19.44 \pm 3.69$ & $10.06 \pm 2.49$ & $91.32 \pm 11.79$ \\
\hline Test and & $t=1.009$ & $t=.597$ & $t=2.493$ & $t=1.223$ & $t=1.302$ & $t=1.146$ \\
\hline $\mathrm{p}$ value & $p=0.319$ & $\mathrm{p}=.553$ & $p=.017$ & $p=.228$ & $p=.200$ & $p=.258$ \\
\hline
\end{tabular}

anger management skill; on the other hand, the scores obtained by them from subscales of the scale in the posttest are $25.66 \pm 5.25$ for skill of students to understand the person in conflict with them, $23.88 \pm 4.25$ for listening skills, $19.95 \pm 5.72$ for skill to focus on needs of both parties, $21.11 \pm 3.83$ for social adaptation skill, and $10.87 \pm 2.40$ for anger management skill. For the students in the experimental group, the difference between total mean scores in the pretest and posttest and between mean scores of all subscales in the pretest and posttest is statistically significant $(\mathrm{p}<0.05)$. This result verifies the hypothesis that "conflict resolution education increases the conflict resolution skill scores of nursing students"

Table 3 illustrates the comparison of CRS pretest-posttest mean scores of students in the control group. The scores obtained by them from subscales of the scale in the pretest are $22.60 \pm 4.82$ for skill of students to understand the person in conflict with them, $22.72 \pm 3.45$ for listening skills, $15.60 \pm 3.18$ for skill to focus on needs of both parties, $18.81 \pm 2.80$ for social adaptation skill, and $9.55 \pm 2.42$ for anger management skill; on the other hand, the scores obtained by them from subscales of the scale in the posttest are $21.86 \pm 4.65$ for skill of students to understand the person in conflict with them, $23.13 \pm 4.45$ for listening skills, $16.81 \pm 3.50$ for skill to focus on needs of both parties, $19.44 \pm 3.69$ for social adaptation skill, and $10.06 \pm 2.49$ for anger management skill. While the difference between their total mean scores in the pretest and posttest and between their total mean score and their mean scores of the subscales "skill of students to understand the person in conflict with them", "listening skills", "social adaptation skill", and "anger management skill" in the pretest and posttest is statistically insignificant ( $p>0.05)$; the difference between mean scores of the subscale "skill to focus on needs of both parties" in the pretest and posttest is statistically significant $(\mathrm{p}<0.05)$.

\section{Discussion}

The results of the study conducted to determine the effects of the conflict resolution education given to nursing students on their conflict resolution skill levels are discussed with the relevant literature. Descriptive characteristics of the students in the experimental and control groups and their CRS pretest mean scores show similarity (Table 1, Table 2).

After the education given to students in the experimental group, CRS total mean score is $101.48 \pm 14.24$, and posttest CRS total mean score of students in the control group is $91.32 \pm 11.79$. The difference between posttest mean scores of experimental and control groups is statistically significant $(\mathrm{p}<0.05)$ (Table 2). The studies conducted conclude the conflict resolution education programs performed on various sample groups are effective in having individuals to gain conflict resolution skills based on cooperation. ${ }^{[36-38]}$ This is line with the results of the study.

In Table 3, the difference between pretest and posttest total mean scores of the experimental group and between pretest and posttest mean scores taken by them from the subscales of the scale is statistically significant $(p<0.05)$. In line with results of the study, Çıtak revealed in her study that conflict resolution skill scores of nurses increased at the end of the five-week conflict resolution education given to intensive care nurses. ${ }^{[30]}$ Kestner and Ray, Deutch and Coleman and O'Grady stated in their studies that education of conflict resolution skills increased the conflict resolution skills. ${ }^{[30,39-41]}$ In the study conducted by Kavalc1, at the end of the 10-week conflict resolution skills education given to 10 students attending at the Middle East Technical University, the conflict resolution scores of students in the experimental group significantly increased in comparison with the control group. ${ }^{[25]} \mathrm{In}$ 
the study conducted by Karahan, 16 university students constituting the experimental group received a 10 -session conflict resolution skill education, each session of which lasted 1.5 hours per week, and their conflict resolution skill levels were observed to be positively affected at the end of the education. ${ }^{[27]}$ The results of these studies are in parallel with the results of the study.

While the difference between pretest and posttest total mean scores of the control group and between pretest and posttest mean scores taken by them from the subscales "skill of students to understand the person in conflict with them", "listening skills", "social adaptation skill", and "anger management skill" is statistically insignificant ( $p>0.05)$, the difference between pretest and posttest mean scores of the subscale "skill to focus on needs of both parties" is statistically significant $(\mathrm{p}<0.05)$, (Table 3$)$. Although an increase is observed in the pretest and posttest total mean scores of the control group and the pretest and posttest mean scores of the subscales "listening skills", "social adaptation skill" and "anger management skill", this increase is not statistically significant. The difference between the pretest and posttest mean scores of the subscale "skill to focus on needs of both parties" is statistically significant $(p<0.05)$. This difference is considered to be associated with the nursing education.

\section{Limitations and Generalizability of the Study}

The most important limitation of this study is working with a small group. For this reason, results of this study may be generalized to this study group.

\section{Conclusion}

As a result of this study; Conflict resolution skills of nursing students participating in the ten-week conflict resolution education program increased. An increase was determined in the scores of "skill of students to understand the person in conflict with them", "listening skills", "skill to focus on needs of both parties", "social adaptation skill", and "anger management skill" which are the subscales of the scale. The fact that the trainings of the conflict resolution are long term and are applied to the small groups by using active training methods will provide the successful management of the conflicts experienced as well as the resolution of the conflicts in a positive manner.

\section{Recommendations}

In line with the conclusions obtained from the study, it is recommended to;

- Include the conflict resolution education into the curriculum,

- Include the conflict resolution education as from the first years of the nursing education and continue the education at regular intervals,

- Conduct similar studies with a broader sample size.

\section{References}

1. Taştan N. Çatışma çözme eğitimi ve akran arabuluculuğu. Öner U, editör. Ankara: Nobel Yayınları; 2010.

2. Cüceloğlu D. İnsan ve davranışı psikolojinin temel kavramları. İstanbul: Remzi Kitabevi; 1991.

3. Rehber E. Illköğretim ikinci kademe öğrencilerinin empatik eğilim düzeylerine göre çatışma çözme davranışlarının incelenmesi. Yayımlanmamış Yüksek Lisans Tezi, Adana, Çukurova Üniversitesi Sosyal Bilimler Enstitüsü, 2007.

4. Şahin HN, Basım N, Çetin F. Locus of control and self-concept in interpersonal conflict resolution approaches. Türk Psikiyatri Dergisi 2009;2:15363.

5. Rahim MA. Toward a theory of managing organizational conflict. Int $J$ Conf Manag 2002;13:206-35.

6. Hatipoğlu S. Hemşireliğin dünü, bugünü ve yarını. VII. Ulusal Hemşirelik Kongresi. Erzurum, 22-24 Haziran 1999;6-11.

7. Atalay $\mathrm{M}, \mathrm{Tel} \mathrm{H}$. A vision of baccalaureate and graduate nursing education The next decade. Cumhuriyet Üniversitesi HYO Derg 1999;3:47-54.

8. Elma C, Demir K. Yönetimde çağdaş yaklaşımlar uygulamalar ve sorunlar. Ankara: Anı Yayıncılık; 2000.

9. Schrumpf F, Crawford KD, Bodine JR. Okulda çatışma çözme ve akran arabuluculuk program rehberi. Akbalık GF, Uyarlama. Akbalık GF, Karaduman DB, Çevirenler. Ankara: Imge Kitabevi Yayınları; 2007.

10. Üngüren E. Organization conflict management: a research on hospitality ındustry. Uluslararası Sosyal Araştırmalar Dergisi 2008;1:881-909.

11. Eren E. Yönetim ve organizasyon çağdaş ve küresel yaklaşımlar. İstanbul: Beta Basım A.Ş; 2009.

12. Solmuş T. Örgütlerde kişiler arası-gruplar arası çatışmalar ve çözümleme yaklaşımları. Türk Psikoloji Bülteni 2001;20:40-9.

13. Huber D. Leadership and nursing care management. St Louis: Elsevier; 1996.

14. Karip E. Çatışma yönetimi. Ankara: Pegem Yayıncılık; 2000.

15. Rahim MA. Managing conflict in organizations. 4th ed. New Jersey: 2011.

16. Aslan Ö, Vural H. Yönetici hemşirelerin çalıştıkları ortamda karşılaştıkları çatışma nedenlerinin ve kullandıkları çatışma yönetim yaklaşımlarının belirlenmesi. Hemşirelik Forumu 2001;4:42-8.

17. Baykal Ü, Seren Ş. Comparison of the tendency of conflict solving nursing and medical students. İ.Ü. Florence Nightingale Hemşirelik Dergisi 2004;13:134-45.

18. Tomey AM. Nursing management and lidership. 5th ed. Mosby; 1996.

19. Akbalık G. Validity and reliability study of the conflict resolution scale (University Students Form). Türk Psikolojik Danışma ve Rehberlik Dergisi 2001;2:7-13.

20. Şahin Ö, Argon G. Organizational conflict types and the investigation of resolution approaches in nurses. HealtMED 2011;5:724-30.

21. Aydın R, Kutlu Y. Job Satisfaction in nurses and parameters concerning tendency of interpersonal conflict and determining relations betwen job satisfaction and tendency of conflict. Cumhuriyet Üniversitesi Hemşirelik Dergisi 2001;5:37-45.

22. Çimensel I. Hemşirelerin hastanelerdeki örgütsel çatışma nedenlerine ilişkin görüşlerinin incelenmesi. Yayınlanmamış Yüksek Lisans Tezi, İzmir, Ege Üniversitesi, Sağlık Bilimleri Enstitüsü 1999.

23. Ünver S. Örgütsel çatışma ve çatışma çözümleme yaklaşımlarının incelenmesi. Yayınlanmamış Yüksek Lisans Tezi, İzmir, Dokuz Eylül Üniversitesi, Sosyal Bilimler Enstitüsü 2002

24. Özmen F. Örgütsel çatışmalar ve çatışma yönetimi yaklaşımları. Yayınlanmamış Doktora Tezi, Elazığ, Fırat Üniversitesi, Sosyal Bilimler Enstitüsü 1997.

25. Kavalcı Z. Çatışma çözme becerileri eğitimi programının üniversite öğrencilerinin çatışma çözme biçimleri üzerindeki etkisi. Yayınlanmamış Yüksek Lisans Tezi, Ankara, Hacettepe Üniversitesi, Sosyal Bilimler Enstitüsü 2001.

26. Karahan TF. Bir iletişim ve çatışma çözme beceri eğitimi programı́nın üni- 
versite öğrencilerinin güvenlik düzeylerine etkisi. Eğitim Fakültesi Dergisi 2005;18:217-30.

27. Karahan TF. Bir iletişim ve çatışma çözme beceri eğitimi programı́nın üniversite öğrencilerinin çatışma çözme beceri düzeylerine etkisi. Eğitim Araştırmaları 2006;22:150-8.

28. Kantek F, Gezer N. Conflict in schools: student nurses' conflict management styles. Nurse Educ Today 2009;29:100-7.

29. Öz F, Hiçdurmaz D. Conflict Resolution Approaches of Nursing Students. Sağlık Bilimleri Fakültesi Hemşirelik Dergisi 2012;1-15.

30. Çıtak AE. Çatışma çözümü eğitiminin hemşirelerin çatışma çözüm becerisi, yöntemi ve tükenmişlik düzeyine etkisinin incelenmesi. Yayınlanmamış Doktora Tezi, İzmir, Ege Üniversitesi, Sağlık Bilimleri Enstitüsü 2006.

31. Akgün S, Araz A. Anlaşmazlıklarımızı çözebiliriz: Çatışma Çözümü Eğitim Programı. Ankara: Nobel Yayınları; 2010.

32. Türnüklü $A$, Kaçmaz T, Gürler $S$, Kalender $A$, et at. The effects of conflict resolution and peer mediation education on students empathy skills. Education and Science, 2009;34:153.

33. Kuş M. Çatışma çözümü eğitimi programının anadolu lisesi düzeyindeki bir grup öğrencinin çatışma çözme davranışlarına etkisinin incelenmesi. Yayınlanmamış Yüksek Lisans Tezi, İstanbul, Yıldız Teknik Üniversitesi, Sosyal Bilimler Enstitüsü 2007.

34. Bayık A. Hemşirelik araştırmalarında etik. In: Erefe T, editör. Hemşirelikte araştırma ilke süreç ve yöntemleri. İstanbul: Ofset Baskı; 2002. s. 27-48. 35. Ulusoy MF, Uçar H. Araştırma etiği. Ankara: Tasarım Ltd Şti; 2002.

36. Breunlin CD, Bryant-Edwards TL, Hetherington JS. Conflict resolution training as an alternative to suspension for violent behavior. Journal Education Research 2002;61:349-57.

37. Cunningham CE, Cunningham LJ, Martorelli V, Tran A, Young J, Zacharias $R$. The effects of primary division, student-mediated conflict resolution programs on playground aggression. J Child Psychol Psychiatry 1998;39:653-62.

38. Durant RH, Barkin S, Krowchuk DP. Evaluation of a peaceful conflict resolution and violence prevention curriculum for sixth-grade students. J Adolesc Health 2001;28:386-93.

39. Kestner P, Ray P. The conflict resolution training program. Jossey-Bass A Wiley Company, San Francisco: 2002;10-76.

40. Deutch M, Coleman P. The handbook of conflict resolution. Jossey-Bass Publishers, San Francisco: 2000;10-89.

41. Porter-O'Grady T. Constructing a conflict resolution program for health care. Health Care Manage Rev 2004;29:278-83.

- Presented at the 2nd International and 6th National Psychiatric Nursing Congress (October 4-7, 2012, istanbul, Turkey). 